\title{
SLC15 family of peptide transporters in GtoPdb v.2021.3
}

\author{
David T. Thwaites ${ }^{1}$ and Tiziano Verri ${ }^{2}$
}

1. Newcastle University, UK

2. University of Salento, Italy

\begin{abstract}
The Solute Carrier 15 (SLC15) family of peptide transporters, alias $\mathrm{H}^{+}$-coupled oligopeptide cotransporter family, is a group of membrane transporters known for their key role in the cellular uptake of di- and tripeptides (di/tripeptides). Of its members, SLC15A1 (PEPT1) chiefly mediates intestinal absorption of luminal di/tripeptides from overall dietary protein digestion, SLC15A2 (PEPT2) mainly allows renal tubular reuptake of di/tripeptides from ultrafiltration and brain-to-blood efflux of di/tripeptides in the choroid plexus, SLC15A3 (PHT2) and SLC15A4 (PHT1) interact with both di/tripeptides and histidine, e.g. in certain immune cells, and SLC15A5 has unknown physiological function. In addition, the SLC15 family of peptide transporters variably interacts with a very large number of peptidomimetics and peptide-like drugs. It is conceivable, based on the currently acknowledged structural and functional differences, to divide the SLC15 family of peptide transporters into two subfamilies [3].
\end{abstract}

\section{Contents}

This is a citation summary for SLC15 family of peptide transporters in the Guide to Pharmacology database (GtoPdb). It exists purely as an adjunct to the database to facilitate the recognition of citations to and from the database by citation analyzers. Readers will almost certainly want to visit the relevant sections of the database which are given here under database links.

GtoPdb is an expert-driven guide to pharmacological targets and the substances that act on them. GtoPdb is a reference work which is most usefully represented as an on-line database. As in any publication this work should be appropriately cited, and the papers it cites should also be recognized. This document provides a citation for the relevant parts of the database, and also provides a reference list for the research cited by those parts. For further details see [14].

Please note that the database version for the citations given in GtoPdb are to the most recent preceding version in which the family or its subfamilies and targets were substantially changed. The links below are to the current version. If you need to consult the cited version, rather than the most recent version, please contact the GtoPdb curators.

\section{Database links}

SLC15 family of peptide transporters

https://www.guidetopharmacology.org/GRAC/FamilyDisplayForward?familyId=187

Transporters

PEPT1(Peptide transporter 1)

https://www.guidetopharmacology.org/GRAC/ObjectDisplayForward?objectId=984 PEPT2(Peptide transporter 2)

https://www.guidetopharmacology.org/GRAC/ObjectDisplayForward?objectId=985 PHT2(Peptide transporter 3)

https://www.guidetopharmacology.org/GRAC/ObjectDisplayForward?objectId=986 PHT1(Peptide transporter 4) https://www.guidetopharmacology.org/GRAC/ObjectDisplayForward?objectId=987

\section{References}

1. Agu R, Cowley E, Shao D, Macdonald C, Kirkpatrick D, Renton K and Massoud E. (2011) Proton- 
coupled oligopeptide transporter (POT) family expression in human nasal epithelium and their drug transport potential. Mol Pharm 8: 664-72 [PMID:21366347]

2. Akazawa T, Yoshida S, Ohnishi S, Kanazu T, Kawai M and Takahashi K. (2018) Application of Intestinal Epithelial Cells Differentiated from Human Induced Pluripotent Stem Cells for Studies of Prodrug Hydrolysis and Drug Absorption in the Small Intestine. Drug Metab Dispos 46: 14971506 [PMID:30135242]

3. Alexander SPH, Kelly E, Mathie A, Peters JA, Veale EL, Armstrong JF, Faccenda E, Harding SD, Pawson AJ and Sharman JL et al.. (2019) THE CONCISE GUIDE TO PHARMACOLOGY 2019/20: Transporters. Br J Pharmacol 176 Suppl 1: S397-S493 [PMID:31710713]

4. Anand BS, Patel J and Mitra AK. (2003) Interactions of the dipeptide ester prodrugs of acyclovir with the intestinal oligopeptide transporter: competitive inhibition of glycylsarcosine transport in human intestinal cell line-Caco-2. J Pharmacol Exp Ther 304: 781-91 [PMID:12538834]

5. Anderson CM, Jevons M, Thangaraju M, Edwards N, Conlon NJ, Woods S, Ganapathy V and Thwaites DT. (2010) Transport of the photodynamic therapy agent 5-aminolevulinic acid by distinct H+-coupled nutrient carriers coexpressed in the small intestine. J Pharmacol Exp Ther 332: 220-8 [PMID:19789362]

6. Arakawa H, Yamada H, Arai K, Kawanishi T, Nitta N, Shibata S, Matsumoto E, Yano K, Kato Y and Kumamoto T et al.. (2020) Possible utility of peptide-transporter-targeting $\left[{ }^{19} \mathrm{~F}\right]$ dipeptides for visualization of the biodistribution of cancers by nuclear magnetic resonance imaging. Int $J$ Pharm 586: 119575 [PMID:32622809]

7. Balimane P and Sinko P. (2000) Effect of ionization on the variable uptake of valacyclovir via the human intestinal peptide transporter (hPepT1) in CHO cells. Biopharm Drug Dispos 21: 165-74 [PMID:11180195]

8. Balimane PV, Tamai I, Guo A, Nakanishi T, Kitada H, Leibach FH, Tsuji A and Sinko PJ. (1998) Direct evidence for peptide transporter (PepT1)-mediated uptake of a nonpeptide prodrug, valacyclovir. Biochem Biophys Res Commun 250: 246-51 [PMID:9753615]

9. Bhardwaj RK, Herrera-Ruiz D, Eltoukhy N, Saad M and Knipp GT. (2006) The functional evaluation of human peptide/histidine transporter 1 (hPHT1) in transiently transfected COS-7 cells. Eur J Pharm Sci 27: 533-42 [PMID:16289537]

10. Bhardwaj RK, Herrera-Ruiz D, Sinko PJ, Gudmundsson OS and Knipp G. (2005) Delineation of human peptide transporter 1 (hPepT1)-mediated uptake and transport of substrates with varying transporter affinities utilizing stably transfected hPepT1/Madin-Darby canine kidney clones and Caco-2 cells. J Pharmacol Exp Ther 314: 1093-100 [PMID:15901802]

11. Biegel A, Gebauer S, Hartrodt B, Brandsch M, Neubert K and Thondorf I. (2005) Threedimensional quantitative structure-activity relationship analyses of beta-lactam antibiotics and tripeptides as substrates of the mammalian $\mathrm{H}+$ /peptide cotransporter PEPT1. J Med Chem $\mathbf{4 8}$ : 4410-9 [PMID:15974593]

12. Biegel A, Knütter I, Hartrodt B, Gebauer S, Theis S, Luckner P, Kottra G, Rastetter M, Zebisch K and Thondorf I et al.. (2006) The renal type H+/peptide symporter PEPT2: structure-affinity relationships. Amino Acids 31: 137-56 [PMID:16868651]

13. Boscutti G, Nardon C, Marchiò L, Crisma M, Biondi B, Dalzoppo D, Dalla Via L, Formaggio F, Casini A and Fregona D. (2018) Anticancer Gold(III) Peptidomimetics: From Synthesis to in vitro and ex vivo Biological Evaluations. ChemMedChem 13: 1131-1145 [PMID:29570944]

14. Buneman P, Christie G, Davies JA, Dimitrellou R, Harding SD, Pawson AJ, Sharman JL and Wu Y. (2020) Why data citation isn't working, and what to do about it Database $\mathbf{2 0 2 0}$ [PMID:32367113]

15. Buyse M, Berlioz F, Guilmeau S, Tsocas A, Voisin T, Péranzi G, Merlin D, Laburthe M, Lewin MJ and Rozé C et al.. (2001) PepT1-mediated epithelial transport of dipeptides and cephalexin is enhanced by luminal leptin in the small intestine. J Clin Invest 108: 1483-94 [PMID:11714740]

16. Buyse M, Charrier L, Sitaraman S, Gewirtz A and Merlin D. (2003) Interferon-gamma increases hPepT1-mediated uptake of di-tripeptides including the bacterial tripeptide fMLP in polarized intestinal epithelia. Am J Pathol 163: 1969-77 [PMID:14578196]

17. Cang J, Zhang J, Wang C, Liu Q, Meng Q, Wang D, Sugiyama Y, Tsuji A, Kaku T and Liu K. (2010) Pharmacokinetics and mechanism of intestinal absorption of JBP485 in rats. Drug Metab Pharmacokinet 25: 500-7 [PMID:20877133]

18. Charrier L, Driss A, Yan Y, Nduati V, Klapproth JM, Sitaraman SV and Merlin D. (2006) hPepT1 mediates bacterial tripeptide fMLP uptake in human monocytes. Lab Invest 86: 490-503 [PMID:16568107]

19. Cheng C, Huang DC, Zhao LY, Cao CJ and Chen GT. (2019) Preparation and in vitro absorption studies of a novel polysaccharide-iron (III) complex from Flammulina velutipes. Int J Biol Macromol 132: 801-810 [PMID:30953722]

20. Chi H, Gu Y, Xu T and Cao F. (2017) Multifunctional organic-inorganic hybrid nanoparticles and nanosheets based on chitosan derivative and layered double hydroxide: cellular uptake mechanism and application for topical ocular drug delivery. Int J Nanomedicine 12: 1607-1620 [PMID:28280329] 
21. Chu XY, Sánchez-Castaño GP, Higaki K, Oh DM, Hsu CP and Amidon GL. (2001) Correlation between epithelial cell permeability of cephalexin and expression of intestinal oligopeptide transporter. J Pharmacol Exp Ther 299: 575-82 [PMID:11602669]

22. Covitz KM, Amidon GL and Sadée W. (1996) Human dipeptide transporter, hPEPT1, stably transfected into Chinese hamster ovary cells. Pharm Res 13: 1631-4 [PMID:8956326]

23. Dai T, Li N, Zhang L, Zhang Y and Liu Q. (2016) A new target ligand Ser-Glu for PEPT1overexpressing cancer imaging. Int J Nanomedicine 11: 203-12 [PMID:26811678]

24. Darcel NP, Liou AP, Tomé D and Raybould HE. (2005) Activation of vagal afferents in the rat duodenum by protein digests requires PepT1. J Nutr 135: 1491-5 [PMID:15930458]

25. Dieck ST, Heuer H, Ehrchen J, Otto C and Bauer K. (1999) The peptide transporter PepT2 is expressed in rat brain and mediates the accumulation of the fluorescent dipeptide derivative beta-Ala-Lys-Nepsilon-AMCA in astrocytes. Glia 25: 10-20 [PMID:9888294]

26. Du Y, Tian C, Wang M, Huang D, Wei W, Liu Y, Li L, Sun B, Kou L and Kan Q et al.. (2018) Dipeptide-modified nanoparticles to facilitate oral docetaxel delivery: new insights into PepT1mediated targeting strategy. Drug Deliv 25: 1403-1413 [PMID:29890854]

27. Döring F, Walter J, Will J, Föcking M, Boll M, Amasheh S, Clauss W and Daniel H. (1998) Deltaaminolevulinic acid transport by intestinal and renal peptide transporters and its physiological and clinical implications. J Clin Invest 101: 2761-7 [PMID:9637710]

28. Foley DW, Pathak RB, Phillips TR, Wilson GL, Bailey PD, Pieri M, Senan A and Meredith D. (2018) Thiodipeptides targeting the intestinal oligopeptide transporter as a general approach to improving oral drug delivery. Eur J Med Chem 156: 180-189 [PMID:30006163]

29. Fujimoto Y, Ishizaka Y, Tahira T, Sone H, Takahashi H, Enomoto K, Mori M, Sugimura T and Nagao M. (1991) Possible involvement of c-myc but not ras genes in hepatocellular carcinomas developing after spontaneous hepatitis in LEC rats. Mol Carcinog 4: 269-74 [PMID:1714740]

30. Fujita T, Kishida T, Wada M, Okada N, Yamamoto A, Leibach FH and Ganapathy V. (2004) Functional characterization of brain peptide transporter in rat cerebral cortex: identification of the high-affinity type H+/peptide transporter PEPT2. Brain Res 997: 52-61 [PMID:14715149]

31. Ganapathy ME, Brandsch M, Prasad PD, Ganapathy V and Leibach FH. (1995) Differential recognition of beta -lactam antibiotics by intestinal and renal peptide transporters, PEPT 1 and PEPT 2. J Biol Chem 270: 25672-7 [PMID:7592745]

32. Ganapathy ME, Huang W, Wang H, Ganapathy V and Leibach FH. (1998) Valacyclovir: a substrate for the intestinal and renal peptide transporters PEPT1 and PEPT2. Biochem Biophys Res Commun 246: 470-5 [PMID:9610386]

33. Ganapathy ME, Prasad PD, Mackenzie B, Ganapathy V and Leibach FH. (1997) Interaction of anionic cephalosporins with the intestinal and renal peptide transporters PEPT 1 and PEPT 2. Biochim Biophys Acta 1324: 296-308 [PMID:9092716]

34. Geissler S, Hellwig M, Zwarg M, Markwardt F, Henle T and Brandsch M. (2010) Transport of the advanced glycation end products alanylpyrraline and pyrralylalanine by the human protoncoupled peptide transporter hPEPT1. J Agric Food Chem 58: 2543-7 [PMID:20104847]

35. Geissler S, Zwarg M, Knütter I, Markwardt F and Brandsch M. (2010) The bioactive dipeptide anserine is transported by human proton-coupled peptide transporters. FEBS J 277: 790-5 [PMID:20067523]

36. Gleeson JP, Brayden DJ and Ryan SM. (2017) Evaluation of PepT1 transport of food-derived antihypertensive peptides, Ile-Pro-Pro and Leu-Lys-Pro using in vitro, ex vivo and in vivo transport models. Eur J Pharm Biopharm 115: 276-284 [PMID:28315445]

37. Gleeson JP, Frías JM, Ryan SM and Brayden DJ. (2018) Sodium caprate enables the blood pressure-lowering effect of Ile-Pro-Pro and Leu-Lys-Pro in spontaneously hypertensive rats by indirectly overcoming PepT1 inhibition. Eur J Pharm Biopharm 128: 179-187 [PMID:29684535]

38. Gong Y, Wu X, Wang T, Zhao J, Liu X, Yao Z, Zhang Q and Jian X. (2017) Targeting PEPT1: a novel strategy to improve the antitumor efficacy of doxorubicin in human hepatocellular carcinoma therapy. Oncotarget 8: 40454-40468 [PMID:28465466]

39. Gong Y, Zhang J, Wu X, Wang T, Zhao J, Yao Z, Zhang Q, Liu X and Jian X. (2017) Specific expression of proton-coupled oligopeptide transporter 1 in primary hepatocarcinoma-a novel strategy for tumor-targeted therapy. Oncol Lett 14: 4158-4166 [PMID:28943923]

40. Gourdon B, Chemin C, Moreau A, Arnauld T, Baumy P, Cisternino S, Péan JM and Declèves X. (2017) Functionalized PLA-PEG nanoparticles targeting intestinal transporter PepT1 for oral delivery of acyclovir. Int J Pharm 529: 357-370 [PMID:28705621]

41. Gourdon B, Chemin C, Moreau A, Arnauld T, Delbos JM, Péan JM and Declèves X. (2018) Influence of PLA-PEG nanoparticles manufacturing process on intestinal transporter PepT1 targeting and oxytocin transport. Eur J Pharm Biopharm 129: 122-133 [PMID:29803721]

42. Groneberg DA, Döring F, Eynott PR, Fischer A and Daniel H. (2001) Intestinal peptide transport: ex vivo uptake studies and localization of peptide carrier PEPT1. Am J Physiol Gastrointest Liver Physiol 281: G697-704 [PMID:11518682]

43. Gu Y, Xu C, Wang Y, Zhou X, Fang L and Cao F. (2019) Multifunctional Nanocomposites Based on Liposomes and Layered Double Hydroxides Conjugated with Glycylsarcosine for Efficient 
Topical Drug Delivery to the Posterior Segment of the Eye. Mol Pharm 16: 2845-2857 [PMID:31244219]

44. Guo A, Hu P, Balimane PV, Leibach FH and Sinko PJ. (1999) Interactions of a nonpeptidic drug, valacyclovir, with the human intestinal peptide transporter (hPEPT1) expressed in a mammalian cell line. J Pharmacol Exp Ther 289: 448-54 [PMID:10087037]

45. Gupta D, Varghese Gupta S, Dahan A, Tsume Y, Hilfinger J, Lee KD and Amidon GL. (2013) Increasing oral absorption of polar neuraminidase inhibitors: a prodrug transporter approach applied to oseltamivir analogue. Mol Pharm 10: 512-22 [PMID:23244438]

46. Gupta SV, Gupta D, Sun J, Dahan A, Tsume Y, Hilfinger J, Lee KD and Amidon GL. (2011) Enhancing the intestinal membrane permeability of zanamivir: a carrier mediated prodrug approach. Mol Pharm 8: 2358-67 [PMID:21905667]

47. Han H, de Vrueh RL, Rhie JK, Covitz KM, Smith PL, Lee CP, Oh DM, Sadée W and Amidon GL. (1998) 5'-Amino acid esters of antiviral nucleosides, acyclovir, and AZT are absorbed by the intestinal PEPT1 peptide transporter. Pharm Res 15: 1154-9 [PMID:9706043]

48. Hellwig M, Geissler S, Matthes R, Peto A, Silow C, Brandsch M and Henle T. (2011) Transport of free and peptide-bound glycated amino acids: synthesis, transepithelial flux at Caco-2 cell monolayers, and interaction with apical membrane transport proteins. Chembiochem 12: 1270-9 [PMID:21538757]

49. Herrera-Ruiz D, Faria TN, Bhardwaj RK, Timoszyk J, Gudmundsson OS, Moench P, Wall DA, Smith RL and Knipp GT. (2004) A novel hPepT1 stably transfected cell line: establishing a correlation between expression and function. Mol Pharm 1: 136-44 [PMID:15832510]

50. Hu Y, Song F, Jiang H, Nuñez G and Smith DE. (2018) SLC15A2 and SLC15A4 Mediate the Transport of Bacterially Derived Di/Tripeptides To Enhance the Nucleotide-Binding Oligomerization Domain-Dependent Immune Response in Mouse Bone Marrow-Derived Macrophages. J Immunol 201: 652-662 [PMID:29784761]

51. Hu Y, Xie Y, Keep RF and Smith DE. (2014) Divergent developmental expression and function of the proton-coupled oligopeptide transporters PepT2 and PhT1 in regional brain slices of mouse and rat. J Neurochem 129: 955-65 [PMID:24548120]

52. Incecayir T, Sun J, Tsume Y, Xu H, Gose T, Nakanishi T, Tamai I, Hilfinger J, Lipka E and Amidon GL. (2016) Carrier-Mediated Prodrug Uptake to Improve the Oral Bioavailability of Polar Drugs: An Application to an Oseltamivir Analogue. J Pharm Sci 105: 925-934 [PMID:26869437]

53. Irie M, Terada T, Sawada K, Saito H and Inui K. (2001) Recognition and transport characteristics of nonpeptidic compounds by basolateral peptide transporter in Caco- 2 cells. $J$ Pharmacol Exp Ther 298: 711-7 [PMID:11454935]

54. Ismair MG, Vavricka SR, Kullak-Ublick GA, Fried M, Mengin-Lecreulx D and Girardin SE. (2006) hPepT1 selectively transports muramyl dipeptide but not Nod1-activating muramyl peptides. Can J Physiol Pharmacol 84: 1313-9 [PMID:17487240]

55. Iwao T, Toyota M, Miyagawa Y, Okita H, Kiyokawa N, Akutsu H, Umezawa A, Nagata K and Matsunaga T. (2014) Differentiation of human induced pluripotent stem cells into functional enterocyte-like cells using a simple method. Drug Metab Pharmacokinet 29: 44-51 [PMID:23822979]

56. Jappar D, Wu SP, Hu Y and Smith DE. (2010) Significance and regional dependency of peptide transporter (PEPT) 1 in the intestinal permeability of glycylsarcosine: in situ single-pass perfusion studies in wild-type and Pept1 knockout mice. Drug Metab Dispos 38: 1740-6 [PMID:20660104]

57. Jiang Q, Zhang J, Tong P, Gao Y, Lv Y, Wang C, Luo M, Sun M, Wang J and Feng Y et al.. (2019) Bioactivatable Pseudotripeptidization of Cyclic Dipeptides To Increase the Affinity toward Oligopeptide Transporter 1 for Enhanced Oral Absorption: An Application to Cyclo(l-Hyp-l-Ser) (JBP485). J Med Chem 62: 7708-7721 [PMID:31393124]

58. Jin Y, Liu Q, Zhou C, Hu X, Wang L, Han S, Zhou Y and Liu Y. (2019) Intestinal oligopeptide transporter PepT1-targeted polymeric micelles for further enhancing the oral absorption of water-insoluble agents. Nanoscale 11: 21433-21448 [PMID:31681915]

59. Knütter I, Hartrodt B, Theis S, Foltz M, Rastetter M, Daniel H, Neubert K and Brandsch M. (2004) Analysis of the transport properties of side chain modified dipeptides at the mammalian peptide transporter PEPT1. Eur J Pharm Sci 21: 61-7 [PMID:14706812]

60. Knütter I, Kottra G, Fischer W, Daniel H and Brandsch M. (2009) High-affinity interaction of sartans with H+/peptide transporters. Drug Metab Dispos 37: 143-9 [PMID:18824524]

61. Knütter I, Theis S, Hartrodt B, Born I, Brandsch M, Daniel H and Neubert K. (2001) A novel inhibitor of the mammalian peptide transporter PEPT1. Biochemistry 40: 4454-8 [PMID:11284702]

62. Knütter I, Wollesky C, Kottra G, Hahn MG, Fischer W, Zebisch K, Neubert RH, Daniel H and Brandsch M. (2008) Transport of angiotensin-converting enzyme inhibitors by $\mathrm{H}+/$ peptide transporters revisited. J Pharmacol Exp Ther 327: 432-41 [PMID:18713951]

63. Kobayashi T, Shimabukuro-Demoto S, Yoshida-Sugitani R, Furuyama-Tanaka K, Karyu H, Sugiura Y, Shimizu Y, Hosaka T, Goto M and Kato N et al.. (2014) The histidine transporter 
SLC15A4 coordinates mTOR-dependent inflammatory responses and pathogenic antibody production. Immunity 41: 375-88 [PMID:25238095]

64. Kottra G, Spanier B, Verri T and Daniel H. (2013) Peptide transporter isoforms are discriminated by the fluorophore-conjugated dipeptides $\beta$-Ala- and d-Ala-Lys-N-7-amino-4methylcoumarin-3-acetic acid. Physiol Rep 1: e00165 [PMID:24744852]

65. Kudo M, Kobayashi-Nakamura K, Kitajima N and Tsuji-Naito K. (2020) Alternate expression of PEPT1 and PEPT2 in epidermal differentiation is required for NOD2 immune responses by bacteria-derived muramyl dipeptide. Biochem Biophys Res Commun 522: 151-156 [PMID:31757425]

66. Landowski CP, Song X, Lorenzi PL, Hilfinger JM and Amidon GL. (2005) Floxuridine amino acid ester prodrugs: enhancing Caco-2 permeability and resistance to glycosidic bond metabolism. Pharm Res 22: 1510-8 [PMID:16132363]

67. Landowski CP, Vig BS, Song X and Amidon GL. (2005) Targeted delivery to PEPT1overexpressing cells: acidic, basic, and secondary floxuridine amino acid ester prodrugs. $\mathrm{Mol}$ Cancer Ther 4: 659-67 [PMID:15827340]

68. Lee J, Tattoli I, Wojtal KA, Vavricka SR, Philpott DJ and Girardin SE. (2009) pH-dependent internalization of muramyl peptides from early endosomes enables Nod1 and Nod2 signaling. $J$ Biol Chem 284: 23818-29 [PMID:19570976]

69. Li M, Anderson GD, Phillips BR, Kong W, Shen DD and Wang J. (2006) Interactions of amoxicillin and cefaclor with human renal organic anion and peptide transporters. Drug Metab Dispos 34: 547-55 [PMID:16434549]

70. Li T, Wu D, Yang Y, Xiao T, Han Y, Li J, Liu T, Li L, Dai Z and Li Y et al.. (2020) Synthesis, pharmacological evaluation and mechanistic study of scutellarin methyl ester -4'-dipeptide conjugates for the treatment of hypoxic-ischemic encephalopathy (HIE) in rat pups. Bioorg Chem 101: 103980 [PMID:32540782]

71. Liu W, Liang R, Ramamoorthy S, Fei YJ, Ganapathy ME, Hediger MA, Ganapathy V and Leibach FH. (1995) Molecular cloning of PEPT 2, a new member of the H+/peptide cotransporter family, from human kidney. Biochim Biophys Acta 1235: 461-6 [PMID:7756356]

72. Liu Z, Wang C, Liu Q, Meng Q, Cang J, Mei L, Kaku T and Liu K. (2011) Uptake, transport and regulation of JBP485 by PEPT1 in vitro and in vivo. Peptides 32: 747-54 [PMID:21262302]

73. Lu X, Chan T, Xu C, Zhu L, Zhou QT, Roberts KD, Chan HK, Li J and Zhou F. (2016) Human oligopeptide transporter 2 (PEPT2) mediates cellular uptake of polymyxins. J Antimicrob Chemother 71: 403-12 [PMID:26494147]

74. Luckner P and Brandsch M. (2005) Interaction of 31 beta-lactam antibiotics with the $\mathrm{H}+/$ peptide symporter PEPT2: analysis of affinity constants and comparison with PEPT1. Eur J Pharm Biopharm 59: 17-24 [PMID:15567297]

75. Ma GG, Shi B, Zhang XP, Qiu Y, Tu GW and Luo Z. (2019) The pathways and mechanisms of muramyl dipeptide transcellular transport mediated by PepT1 in enterogenous infection. Ann Transl Med 7: 473 [PMID:31700909]

76. Mandal A, Pal D and Mitra AK. (2016) Circumvention of P-gp and MRP2 mediated efflux of lopinavir by a histidine based dipeptide prodrug. Int J Pharm 512: 49-60 [PMID:27543355]

77. Meredith D, Boyd CA, Bronk JR, Bailey PD, Morgan KM, Collier ID and Temple CS. (1998) 4aminomethylbenzoic acid is a non-translocated competitive inhibitor of the epithelial peptide transporter PepT1.J Physiol (Lond.) 512 ( Pt 3): 629-34 [PMID:9882198]

78. Merlin D, Si-Tahar M, Sitaraman SV, Eastburn K, Williams I, Liu X, Hediger MA and Madara JL. (2001) Colonic epithelial hPepT1 expression occurs in inflammatory bowel disease: transport of bacterial peptides influences expression of MHC class 1 molecules. Gastroenterology 120: 166679 [PMID:11375948]

79. Merlin D, Steel A, Gewirtz AT, Si-Tahar M, Hediger MA and Madara JL. (1998) hPepT1-mediated epithelial transport of bacteria-derived chemotactic peptides enhances neutrophil-epithelial interactions. J Clin Invest 102: 2011-8 [PMID:9835627]

80. Minhas GS and Newstead S. (2019) Structural basis for prodrug recognition by the SLC15 family of proton-coupled peptide transporters. Proc Natl Acad Sci U S A 116: 804-809 [PMID:30602453]

81. Mitsuoka K, Miyoshi S, Kato Y, Murakami Y, Utsumi R, Kubo Y, Noda A, Nakamura Y, Nishimura S and Tsuji A. (2008) Cancer detection using a PET tracer, 11C-glycylsarcosine, targeted to H+/peptide transporter. J Nucl Med 49: 615-22 [PMID:18344442]

82. Miyabe J, Ohgaki R, Saito K, Wei L, Quan L, Jin C, Liu X, Okuda S, Nagamori S and Ohki H et al.. (2019) Boron delivery for boron neutron capture therapy targeting a cancer-upregulated oligopeptide transporter. J Pharmacol Sci 139: 215-222 [PMID:30833090]

83. Miyake M, Fujishima M and Nakai D. (2017) Inhibitory Potency of Marketed Drugs for Ulcerative Colitis and Crohn's Disease on PEPT1. Biol Pharm Bull 40: 1572-1575 [PMID:28867741]

84. Molotkov A, Castrillon JW, Santha S, Harris PE, Leung DK, Mintz A and Carberry P. (2020) The Radiolabeling of a Gly-Sar Dipeptide Derivative with Flourine-18 and Its Use as a Potential 
Peptide Transporter PET Imaging Agent. Molecules 25 [PMID:32024310]

85. Nabulsi NB, Smith DE and Kilbourn MR. (2005) [11C]Glycylsarcosine: synthesis and in vivo evaluation as a PET tracer of PepT2 transporter function in kidney of PepT2 null and wild-type mice. Bioorg Med Chem 13: 2993-3001 [PMID:15781409]

86. Nakamura N, Lill JR, Phung Q, Jiang Z, Bakalarski C, de Mazière A, Klumperman J, Schlatter M, Delamarre L and Mellman I. (2014) Endosomes are specialized platforms for bacterial sensing and NOD2 signalling. Nature 509: 240-4 [PMID:24695226]

87. Neumann J and Brandsch M. (2003) Delta-aminolevulinic acid transport in cancer cells of the human extrahepatic biliary duct. J Pharmacol Exp Ther 305: 219-24 [PMID:12649372]

88. Neumann J, Bruch M, Gebauer S and Brandsch M. (2004) Transport of the phosphonodipeptide alafosfalin by the $\mathrm{H}+$ /peptide cotransporters PEPT1 and PEPT2 in intestinal and renal epithelial cells. Eur J Biochem 271: 2012-7 [PMID:15128310]

89. Ocheltree SM, Shen H, Hu Y, Xiang J, Keep RF and Smith DE. (2004) Mechanisms of cefadroxil uptake in the choroid plexus: studies in wild-type and PEPT2 knockout mice. J Pharmacol Exp Ther 308: 462-7 [PMID:14600253]

90. Oppermann H, Heinrich M, Birkemeyer C, Meixensberger J and Gaunitz F. (2019) The protoncoupled oligopeptide transporters PEPT2, PHT1 and PHT2 mediate the uptake of carnosine in glioblastoma cells. Amino Acids 51: 999-1008 [PMID:31073693]

91. Otter M, Oswald S, Siegmund W and Keiser M. (2017) Effects of frequently used pharmaceutical excipients on the organic cation transporters 1-3 and peptide transporters $1 / 2$ stably expressed in MDCKII cells. Eur J Pharm Biopharm 112: 187-195 [PMID:27903454]

92. Rohm F, Daniel H and Spanier B. (2019) Transport Versus Hydrolysis: Reassessing Intestinal Assimilation of Di- and Tripeptides by LC-MS/MS Analysis. Mol Nutr Food Res 63: e1900263 [PMID:31394017]

93. Rohm F, Skurk T, Daniel H and Spanier B. (2019) Appearance of Di- and Tripeptides in Human Plasma after a Protein Meal Does Not Correlate with PEPT1 Substrate Selectivity. Mol Nutr Food Res 63: e1801094 [PMID:30521147]

94. Romano A, Barca A, Kottra G, Daniel H, Storelli C and Verri T. (2010) Functional expression of SLC15 peptide transporters in rat thyroid follicular cells. Mol Cell Endocrinol 315: 174-81 [PMID:19913073]

95. Rühl A, Hoppe S, Frey I, Daniel H and Schemann M. (2005) Functional expression of the peptide transporter PEPT2 in the mammalian enteric nervous system. J Comp Neurol 490: 1-11 [PMID:16041713]

96. Sakata K, Yamashita T, Maeda M, Moriyama Y, Shimada S and Tohyama M. (2001) Cloning of a lymphatic peptide/histidine transporter. Biochem J 356: 53-60 [PMID:11336635]

97. Sala-Rabanal M, Loo DD, Hirayama BA, Turk E and Wright EM. (2006) Molecular interactions between dipeptides, drugs and the human intestinal $\mathrm{H}+$-oligopeptide cotransporter hPEPT1.J Physiol (Lond.) 574: 149-66 [PMID:16627568]

98. Sala-Rabanal M, Loo DD, Hirayama BA and Wright EM. (2008) Molecular mechanism of dipeptide and drug transport by the human renal H+/oligopeptide cotransporter hPEPT2. Am J Physiol Renal Physiol 294: F1422-32 [PMID:18367661]

99. Sasawatari S, Okamura T, Kasumi E, Tanaka-Furuyama K, Yanobu-Takanashi R, Shirasawa S, Kato N and Toyama-Sorimachi N. (2011) The solute carrier family 15A4 regulates TLR9 and NOD1 functions in the innate immune system and promotes colitis in mice. Gastroenterology 140: 1513-25 [PMID:21277849]

100. Sawada K, Terada T, Saito H, Hashimoto Y and Inui K. (1999) Effects of glibenclamide on glycylsarcosine transport by the rat peptide transporters PEPT1 and PEPT2. Br J Pharmacol 128: 1159-64 [PMID:10578127]

101. Song F, Hu Y, Jiang H and Smith DE. (2017) Species Differences in Human and Rodent PEPT2Mediated Transport of Glycylsarcosine and Cefadroxil in Pichia Pastoris Transformants. Drug Metab Dispos 45: 130-136 [PMID:27836942]

102. Song F, Hu Y, Wang Y, Smith DE and Jiang H. (2018) Functional Characterization of Human Peptide/Histidine Transporter 1 in Stably Transfected MDCK Cells. Mol Pharm 15: 385-393 [PMID:29224352]

103. Song F, Yi Y, Li C, Hu Y, Wang J, Smith DE and Jiang H. (2018) Regulation and biological role of the peptide/histidine transporter SLC15A3 in Toll-like receptor-mediated inflammatory responses in macrophage. Cell Death Dis 9: 770 [PMID:29991810]

104. Song X, Lorenzi PL, Landowski CP, Vig BS, Hilfinger JM and Amidon GL. (2005) Amino acid ester prodrugs of the anticancer agent gemcitabine: synthesis, bioconversion, metabolic bioevasion, and hPEPT1-mediated transport. Mol Pharm 2: 157-67 [PMID:15804190]

105. Sreedharan S, Stephansson O, Schiöth HB and Fredriksson R. (2011) Long evolutionary conservation and considerable tissue specificity of several atypical solute carrier transporters. Gene 478: 11-8 [PMID:21044875]

106. Sugawara M, Huang W, Fei YJ, Leibach FH, Ganapathy V and Ganapathy ME. (2000) Transport of valganciclovir, a ganciclovir prodrug, via peptide transporters PEPT1 and PEPT2. J Pharm Sci 
89: 781-9 [PMID:10824137]

107. Sun D, Wang Y, Tan F, Fang D, Hu Y, Smith DE and Jiang H. (2013) Functional and molecular expression of the proton-coupled oligopeptide transporters in spleen and macrophages from mouse and human. Mol Pharm 10: 1409-16 [PMID:23442152]

108. Sun Y, Gan W, Lei M, Jiang W, Cheng M, He J, Sun Q, Liu W, Hu L and Jin Y. (2018) PEPT1mediated prodrug strategy for oral delivery of peramivir. Asian J Pharm Sci 13: 555-565 [PMID:32104429]

109. Swaan PW, Bensman T, Bahadduri PM, Hall MW, Sarkar A, Bao S, Khantwal CM, Ekins S and Knoell DL. (2008) Bacterial peptide recognition and immune activation facilitated by human peptide transporter PEPT2. Am J Respir Cell Mol Biol 39: 536-42 [PMID:18474668]

110. Tai W, Chen Z and Cheng K. (2013) Expression profile and functional activity of peptide transporters in prostate cancer cells. Mol Pharm 10: 477-87 [PMID:22950754]

111. Tamai I, Nakanishi T, Hayashi K, Terao T, Sai Y, Shiraga T, Miyamoto K, Takeda E, Higashida H and Tsuji A. (1997) The predominant contribution of oligopeptide transporter PepT1 to intestinal absorption of beta-lactam antibiotics in the rat small intestine. J Pharm Pharmacol 49: $796-801$ [PMID:9379359]

112. Tamai I, Nakanishi T, Nakahara H, Sai Y, Ganapathy V, Leibach FH and Tsuji A. (1998) Improvement of L-dopa absorption by dipeptidyl derivation, utilizing peptide transporter PepT1. J Pharm Sci 87: 1542-6 [PMID:10189264]

113. Tao W, Zhao D, Sun M, Li M, Zhang X, He Z, Sun Y and Sun J. (2017) Enzymatic activation of double-targeted 5'-O-L-valyl-decitabine prodrug by biphenyl hydrolase-like protein and its molecular design basis. Drug Deliv Transl Res 7: 304-311 [PMID:28070705]

114. Tao W, Zhao D, Sun M, Wang Z, Lin B, Bao Y, Li Y, He Z, Sun Y and Sun J. (2018) Intestinal absorption and activation of decitabine amino acid ester prodrugs mediated by peptide transporter PEPT1 and enterocyte enzymes. Int J Pharm 541: 64-71 [PMID:29471144]

115. Terada T, Saito H, Mukai M and Inui K. (1997) Recognition of beta-lactam antibiotics by rat peptide transporters, PEPT1 and PEPT2, in LLC-PK1 cells. Am J Physiol 273: F706-11 [PMID:9374833]

116. Terada T, Saito H, Mukai M and Inui KI. (1996) Identification of the histidine residues involved in substrate recognition by a rat $\mathrm{H}+/$ peptide cotransporter, PEPT1. FEBS Lett 394: 196-200 [PMID:8843163]

117. Terada T, Sawada K, Saito H, Hashimoto Y and Inui K. (2000) Inhibitory effect of novel oral hypoglycemic agent nateglinide (AY4166) on peptide transporters PEPT1 and PEPT2. Eur J Pharmacol 392: 11-7 [PMID:10748266]

118. Theis S, Hartrodt B, Kottra G, Neubert K and Daniel H. (2002) Defining minimal structural features in substrates of the $\mathrm{H}(+)$ /peptide cotransporter PEPT2 using novel amino acid and dipeptide derivatives. Mol Pharmacol 61: 214-21 [PMID:11752223]

119. Theis S, Knutter I, Hartrodt B, Brandsch M, Kottra G, Neubert K and Daniel H. (2002) Synthesis and characterization of high affinity inhibitors of the $\mathrm{H}+/$ peptide transporter PEPT2.J Biol Chem 277: 7287-92 [PMID:11751927]

120. Thompson BR, Shi J, Zhu HJ and Smith DE. (2020) Pharmacokinetics of gemcitabine and its amino acid ester prodrug following intravenous and oral administrations in mice. Biochem Pharmacol 180: 114127 [PMID:32603666]

121. Tsuji A. (1999) Tissue selective drug delivery utilizing carrier-mediated transport systems. $J$ Control Release 62: 239-44 [PMID:10518656]

122. Tsume Y, Hilfinger JM and Amidon GL. (2008) Enhanced cancer cell growth inhibition by dipeptide prodrugs of floxuridine: increased transporter affinity and metabolic stability. Mol Pharm 5: 717-27 [PMID:18652477]

123. Tsume Y, Vig BS, Sun J, Landowski CP, Hilfinger JM, Ramachandran C and Amidon GL. (2008) Enhanced absorption and growth inhibition with amino acid monoester prodrugs of floxuridine by targeting hPEPT1 transporters. Molecules 13: 1441-54 [PMID:18719516]

124. Ural-Blimke Y, Flayhan A, Strauss J, Rantos V, Bartels K, Nielsen R, Pardon E, Steyaert J, Kosinski J and Quistgaard EM et al.. (2019) Structure of Prototypic Peptide Transporter DtpA from E. coli in Complex with Valganciclovir Provides Insights into Drug Binding of Human PepT1.J Am Chem Soc 141: 2404-2412 [PMID:30644743]

125. Vavricka SR, Musch MW, Chang JE, Nakagawa Y, Phanvijhitsiri K, Waypa TS, Merlin D, Schneewind O and Chang EB. (2004) hPepT1 transports muramyl dipeptide, activating NFkappaB and stimulating IL-8 secretion in human colonic Caco2/bbe cells. Gastroenterology 127 : 1401-9 [PMID:15521010]

126. Vig BS, Stouch TR, Timoszyk JK, Quan Y, Wall DA, Smith RL and Faria TN. (2006) Human PEPT1 pharmacophore distinguishes between dipeptide transport and binding. J Med Chem 49: 3636-44 [PMID:16759105]

127. Wang CL, Fan YB, Lu HH, Tsai TH, Tsai MC and Wang HP. (2010) Evidence of D-phenylglycine as delivering tool for improving L-dopa absorption. J Biomed Sci 17: 71 [PMID:20815935]

128. Wang J, Wang L, Li Y, Wang X and Tu P. (2018) Apically targeted oral micelles exhibit highly 
efficient intestinal uptake and oral absorption. Int J Nanomedicine 13: 7997-8012 [PMID:30538473]

129. Wang XX, Hu Y, Keep RF, Toyama-Sorimachi N and Smith DE. (2017) A novel role for PHT1 in the disposition of l-histidine in brain: In vitro slice and in vivo pharmacokinetic studies in wildtype and Pht1 null mice. Biochem Pharmacol 124: 94-102 [PMID:27845049]

130. Wang XX, Li YB, Feng MR and Smith DE. (2018) Semi-Mechanistic Population Pharmacokinetic Modeling of L-Histidine Disposition and Brain Uptake in Wildtype and Pht1 Null Mice. Pharm Res 35: 19 [PMID:29305823]

131. Wang Y, Hu Y, Li P, Weng Y, Kamada N, Jiang H and Smith DE. (2018) Expression and regulation of proton-coupled oligopeptide transporters in colonic tissue and immune cells of mice. Biochem Pharmacol 148: 163-173 [PMID:29305856]

132. Wang Y, Li P, Song F, Yang X, Weng Y, Ma Z, Wang L and Jiang H. (2019) Substrate Transport Properties of the Human Peptide/Histidine Transporter PHT2 in Transfected MDCK Cells. J Pharm Sci 108: 3416-3424 [PMID:31254495]

133. Wang Y, Zhou L, Fang L and Cao F. (2020) Multifunctional carboxymethyl chitosan derivativeslayered double hydroxide hybrid nanocomposites for efficient drug delivery to the posterior segment of the eye. Acta Biomater 104: 104-114 [PMID:31931169]

134. Wenzel U, Diehl D, Herget $M$ and Daniel H. (1998) Endogenous expression of the renal highaffinity H+-peptide cotransporter in LLC-PK1 cells. Am J Physiol 275: C1573-9 [PMID:9843719]

135. Wenzel U, Gebert I, Weintraut H, Weber WM, Clauss W and Daniel H. (1996) Transport characteristics of differently charged cephalosporin antibiotics in oocytes expressing the cloned intestinal peptide transporter PepT1 and in human intestinal Caco-2 cells. J Pharmacol Exp Ther 277: 831-9 [PMID:8627565]

136. Wu Q, He X, Zhou S, Shi F and Lu Y. (2020) Role of PEPT1in the transport of cinnabar in Caco-2 cells. Toxicol In Vitro 63: 104747 [PMID:31838184]

137. Wu SP and Smith DE. (2013) Impact of intestinal PepT1 on the kinetics and dynamics of Nformyl-methionyl-leucyl-phenylalanine, a bacterially-produced chemotactic peptide. Mol Pharm 10: 677-84 [PMID:23259992]

138. Wu Y, Sun M, Wang D, Li G, Huang J, Tan S, Bao L, Li Q, Li G and Si L. (2019) A PepT1 mediated medicinal nano-system for targeted delivery of cyclosporine A to alleviate acute severe ulcerative colitis. Biomater Sci 7: 4299-4309 [PMID:31408067]

139. Xiang J, Hu Y, Smith DE and Keep RF. (2006) PEPT2-mediated transport of 5-aminolevulinic acid and carnosine in astrocytes. Brain Res 1122: 18-23 [PMID:17034769]

140. Xu Q, Wang C, Meng Q, Liu Q, Sun P, Sun H, Guo X and Liu K. (2014) The oligopeptide transporter 2-mediated reabsorption of entecavir in rat kidney. Eur J Pharm Sci 52: 41-7 [PMID:24184752]

141. Xu T, Xu X, Gu Y, Fang L and Cao F. (2018) Functional intercalated nanocomposites with chitosan-glutathione-glycylsarcosine and layered double hydroxides for topical ocular drug delivery. Int J Nanomedicine 13: 917-937 [PMID:29491707]

142. Xu T, Zhang J, Chi H and Cao F. (2016) Multifunctional properties of organic-inorganic hybrid nanocomposites based on chitosan derivatives and layered double hydroxides for ocular drug delivery. Acta Biomater 36: 152-63 [PMID:26940970]

143. Xu X, Sun L, Zhou L, Cheng Y and Cao F. (2020) Functional chitosan oligosaccharide nanomicelles for topical ocular drug delivery of dexamethasone. Carbohydr Polym 227: 115356 [PMID:31590850]

144. Yamashita T, Shimada S, Guo W, Sato K, Kohmura E, Hayakawa T, Takagi T and Tohyama M. (1997) Cloning and functional expression of a brain peptide/histidine transporter. J Biol Chem 272: 10205-11 [PMID:9092568]

145. Yan Z, Sun J, Chang Y, Liu Y, Fu Q, Xu Y, Sun Y, Pu X, Zhang Y and Jing Y et al.. (2011) Bifunctional peptidomimetic prodrugs of didanosine for improved intestinal permeability and enhanced acidic stability: synthesis, transepithelial transport, chemical stability and pharmacokinetics. Mol Pharm 8: 319-29 [PMID:21280612]

146. Yuri T, Kono Y, Okada T, Terada T, Miyauchi S and Fujita T. (2020) Transport Characteristics of 5-Aminosalicylic Acid Derivatives Conjugated with Amino Acids via Human $\mathrm{H}^{+}$-Coupled Oligopeptide Transporter PEPT1. Biol Pharm Bull 43: 697-706 [PMID:32238712]

147. Zhang J, Wen H, Shen F, Wang X, Shan C, Chai C, Liu J and Li W. (2019) Synthesis and biological evaluation of a novel series of curcumin-peptide derivatives as PepT1-mediated transport drugs. Bioorg Chem 92: 103163 [PMID:31450166]

148. Zhao D and Lu K. (2015) Substrates of the human oligopeptide transporter hPEPT2. Biosci Trends 9: 207-13 [PMID:26355221]

149. Zimmermann M, Kappert K and Stan AC. (2010) U373-MG cells express PepT2 and accumulate the fluorescently tagged dipeptide-derivative $\beta$-Ala-Lys-N( $\varepsilon$ )-AMCA. Neurosci Lett 486: 174-8 [PMID:20868728]

150. Zimmermann M and Stan AC. (2010) PepT2 transporter protein expression in human neoplastic glial cells and mediation of fluorescently tagged dipeptide derivative beta-Ala-Lys-Nepsilon-7- 
amino-4-methyl-coumarin-3-acetic acid accumulation. J Neurosurg 112: 1005-14 [PMID:19612975] 